\title{
Front Matter: Volume 9380
}

, "Front Matter: Volume 9380," Proc. SPIE 9380, Laser Refrigeration of Solids VIII, 938001 (23 April 2015); doi: 10.1117/12.2192614

SPIE. Event: SPIE OPTO, 2015, San Francisco, California, United States 


\title{
PROCEEDINGS OF SPIE
}

\section{Laser Refrigeration of Solids VIII}

\author{
Richard I. Epstein \\ Denis V. Seletskiy \\ Mansoor Sheik-Bahae \\ Editors
}

11-12 February 2015

San Francisco, California, United States

Sponsored and Published by

SPIE 
The papers included in this volume were part of the technical conference cited on the cover and title page. Papers were selected and subject to review by the editors and conference program committee. Some conference presentations may not be available for publication. The papers published in these proceedings reflect the work and thoughts of the authors and are published herein as submitted. The publisher is not responsible for the validity of the information or for any outcomes resulting from reliance thereon.

Please use the following format to cite material from this book:

Author(s), "Title of Paper," in Laser Refrigeration of Solids VIII, edited by Richard I. Epstein, Denis V. Seletskiy, Mansoor Sheik-Bahae, Proceedings of SPIE Vol. 9380 (SPIE, Bellingham, WA, 2015) Article CID Number.

ISSN: 0277-786X

ISBN: 9781628414707

\section{Published by}

\section{SPIE}

P.O. Box 10, Bellingham, Washington 98227-0010 USA

Telephone +1 3606763290 (Pacific Time) · Fax +1 3606471445

SPIE.org

Copyright (C) 2015, Society of Photo-Optical Instrumentation Engineers.

Copying of material in this book for internal or personal use, or for the internal or personal use of specific clients, beyond the fair use provisions granted by the U.S. Copyright Law is authorized by SPIE subject to payment of copying fees. The Transactional Reporting Service base fee for this volume is $\$ 18.00$ per article (or portion thereof), which should be paid directly to the Copyright Clearance Center (CCC), 222 Rosewood Drive, Danvers, MA 01923. Payment may also be made electronically through CCC Online at copyright.com. Other copying for republication, resale, advertising or promotion, or any form of systematic or multiple reproduction of any material in this book is prohibited except with permission in writing from the publisher. The CCC fee code is 0277-786X/15/\$18.00.

Printed in the United States of America.

Publication of record for individual papers is online in the SPIE Digital Library.

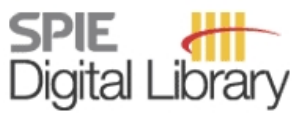

SPIEDigitallibrary.org

Paper Numbering: Proceedings of SPIE follow an e-First publication model, with papers published first online and then in print. Papers are published as they are submitted and meet publication criteria. A unique citation identifier (CID) number is assigned to each article at the time of the first publication. Utilization of CIDs allows articles to be fully citable as soon as they are published online, and connects the same identifier to all online, print, and electronic versions of the publication. SPIE uses a six-digit CID article numbering system in which:

- The first four digits correspond to the SPIE volume number.

- The last two digits indicate publication order within the volume using a Base 36 numbering

system employing both numerals and letters. These two-number sets start with 00, 01, 02, 03, 04, $05,06,07,08,09,0 A, 0 B \ldots$. OZ, followed by 10-1Z, 20-2Z, etc.

The CID Number appears on each page of the manuscript. The complete citation is used on the first page, and an abbreviated version on subsequent pages. 


\title{
Contents
}

\author{
$\checkmark \quad$ Authors \\ vii Conference Committee \\ ix Introduction
}

\section{SESSION 1 CRYOGENIC REFRIGERATION IN RARE-EARTH DOPED SYSTEMS}

938003 Intracavity-enhanced optical refrigeration of Yb:YLF crystal to cryogenic temperatures (Invited Paper) [9380-2]

938004 Purification of precursors of $\mathrm{Yb}^{3+}$-doped YLF crystals by solvent extraction and electrochemical processing (Invited Paper) [9380-3]

\section{SESSION 2 NOVEL RARE-EARTH DOPED SYSTEMS}

938007 Laser-refrigeration of rare-earth-doped nanocrystals in water (Invited Paper) [9380-6]

938008 Optical refrigeration of $\mathrm{Yb}^{3+}:$ YAG nanocrystals [9380-7]

9380 OA Spectroscopic and thermal study of Er-doped oxysulfide crystal powders (Invited Paper) [9380-9]

\section{SESSION 3 LASER COOLING IN SEMICONDUCTORS}

9380 OE Photoluminescence study of suspended MQW structures for laser refrigeration purposes [9380-13]

9380 OF High sensitivity background absorption measurements in semiconductors [9380-14]

\section{SESSION 4 APPLICATIONS AND DEVICE CONCEPTS}

9380 0l Design study of a laser-cooled infrared sensor (Invited Paper) [9380-17]

$9380 \mathrm{JJ}$ Thermal modeling for an optical refrigerator [9380-18]

\section{SESSION 5 NOVEL COOLING CONCEPTS}

9380 OL Optical refrigeration for ultra-efficient photovoltaics (Invited Paper) [9380-20] 
9380 OM A Kennard-Stepanov relation study on redistributional laser cooling in dense gaseous ensembles (Invited Paper) [9380-21]

9380 ON Excitation strategies and propagation effects in laser cooling of solids via superradiance (Invited Paper) [9380-22]

POSTER SESSION

938000 Comparative spectroscopic studies of $\mathrm{Ho}_{0} \mathrm{KPb}_{2} \mathrm{Cl}_{5}, \mathrm{Ho}: \mathrm{KPb}_{2} \mathrm{Br}_{2}$, and $\mathrm{Ho}$ : YAG for $2 \mu \mathrm{m}$ laser cooling applications [9380-23]

9380 OP Nanocrystallization in $\mathrm{Yb}^{3+}$-doped oxyfluoride glasses for laser cooling [9380-24]

$9380 \mathrm{OQ}$ Characterization of fluoride nanocrystals for optical refrigeration [9380-25]

$9380 \mathrm{OR}$ Prospects of optical refrigeration in oxyfluoride glasses and glass-ceramics: experiments [9380-26]

9380 OS Laser cooling of doped crystals by methods of coherent pumping [9380-27] 


\section{Authors}

Numbers in the index correspond to the last two digits of the six-digit citation identifier (CID) article numbering system used in Proceedings of SPIE. The first four digits reflect the volume number. Base 36 numbering is employed for the last two digits and indicates the order of articles within the volume. Numbers start with 00, 01, 02, 03, 04, 05, 06, 07, 08, 09, 0A, 0B...0Z, followed by 10-1Z, 20-2Z, etc.

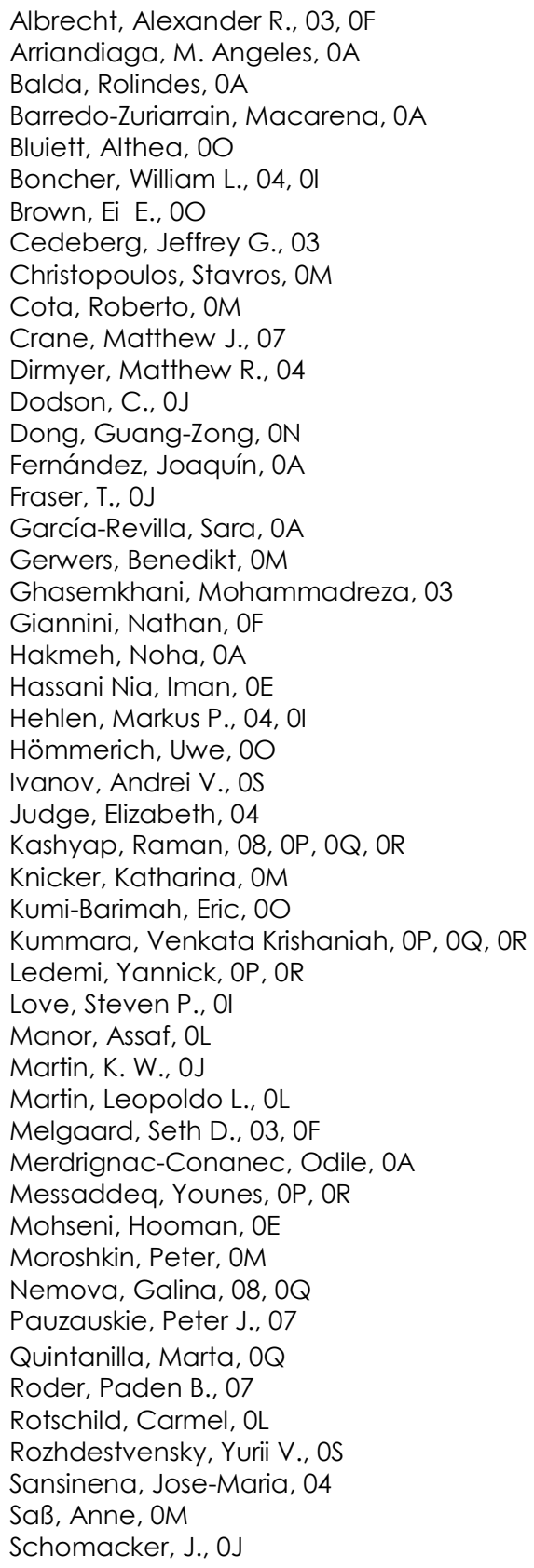

Sheik-Bahae, Mansoor, 03, OF

Silva, Junior R., OF

Smith, Bennett E., 07

Soares de Lima Filho, Elton, OP, OQ, OR

Trivedi, Sudhir B., 00

Vetrone, Fiorenzo, $0 Q$

Wang, Chengao, OF

Weitz, Martin, OM

Weller, Lars, OM

Yu, Ye-Jin, OR

Zhang, Xin-Lu, ON

Zhou, Xuezhe, 07 
Proc. of SPIE Vol. $9380938001-6$

Downloaded From: https://www.spiedigitallibrary.org/conference-proceedings-of-spie on 26 Apr 2023 Terms of Use: https://www.spiedigitallibrary.org/terms-of-use 


\section{Conference Committee}

Symposium Chairs

David L. Andrews, University of East Anglia (United Kingdom)

Alexei L. Glebov, OptiGrate Corporation (United States)

Symposium Co-chairs

Jean-Emmanuel Broquin, IMEP-LAHC (France)

Shibin Jiang, AdValue Photonics, Inc. (United States)

Program Track Chair

Zameer U. Hasan, Temple University (United States)

Conference Chairs

Richard I. Epstein, The University of New Mexico (United States)

Denis V. Seletskiy, Universität Konstanz (Germany)

Mansoor Sheik-Bahae, The University of New Mexico (United States)

Conference Program Committee

Daniel A. Bender, Sandia National Laboratories (United States)

Steven Bowman, U.S. Naval Research Laboratory (United States)

Tal Eliezer Carmon, University of Michigan (United States)

Joaquín Fernández, Universidad del País Vasco (Spain)

Zameer UI Hasan, Temple University (United States)

Raman Kashyap, École Polytechnique de Montréal (Canada)

Paul D. LeVan, Air Force Research Laboratory (United States)

Mauro Tonelli, Università degli Studi di Pisa (Italy)

Qihua Xiong, Nanyang Technological University (Singapore)

Session Chairs

1 Cryogenic Refrigeration in Rare-Earth Doped Systems

Raman Kashyap, École Polytechnique de Montréal (Canada)

2 Novel Rare-Earth Doped Systems

Steven Bowman, U.S. Naval Research Laboratory (United States)

3 Laser Cooling in Semiconductors

Paul D. LeVan, Air Force Research Laboratory (United States) 
4 Applications and Device Concepts

Daniel A. Bender, Sandia National Laboratories (United States)

5 Novel Cooling Concepts

Galina A. Nemova, École Polytechnique de Montréal (Canada) 


\section{Introduction}

2015 is designated as the International Year of Light. This year, we also mark the occasion of the 20th anniversary of the field of laser cooling of solids, following pioneering experiments on first observation of cooling of a ytterbium-doped glass by $0.3 \mathrm{~K}$ starting from room temperature (R. I. Epstein et. al., Nature 377, 500 (1995)).

To rise to these occasions, this year's Laser Refrigeration of Solids VIII (LRS VIII) conference attracted an exciting collection of 27 invited, contributed, and poster talks showcasing advancements in the field, ranging from expanding scientific understanding of laser cooling to novel applications. The papers discussed recent results categorized in five sessions: Cryogenic Refrigeration in Rare-Earth-Doped Systems, Novel Rare-Earth Doped Systems, Laser Cooling in Semiconductors, Applications and Device Concepts, and Novel Cooling Concepts. On one hand, the progress included expansion of the database of rare-earth doped cooling materials comprised now of ytterbium, thulium, erbium, and dysprosium dopants in a variety of crystal and glass hosts, both in bulk and nanoscale geometries. On the other, material science and advanced characterization methods have allowed for improvement of the quality of cooling solids to the point that operating temperatures of 90 Kelvin are now being reported by the University of New Mexico team. Liquid nitrogen temperatures may be within reach in the near future, and this progress motivates the multitude of advanced applications, ranging from basic science ones to space-borne sensor systems. Many of these applications were presented this year in a number of invited and contributed talks.

In parallel with the developments in cooling of insulator-based crystals, the field has witnessed active theoretical and experimental advances in efforts to achieve optical refrigeration of semiconductors. First demonstrations of laser cooling of II$\mathrm{VI}$ materials and record-breaking external quantum efficiency in III-V semiconductor heterostructures have marked milestone achievements in this direction a few years ago. This year's meeting elaborated on new strategies for increasing performance in laser cooling of semiconductors together with development of advanced methods of high precision characterization of materials.

Novel laser cooling applications that go beyond the aforementioned themes have seen new results, covering the topics of ultrastable lasers, design of lowthermal-noise coatings, design studies of laser-cooled infrared sensors and thermal link modeling. Additionally, new aspects of laser cooling included topics on optically-cooled solid state lasers, optical-refrigeration for ultra-efficient photovoltaics, redistributional laser cooling of gases and laser cooling via superradiance. 
We are very happy to acknowledge the growth of our community of optical refrigeration by announcing a new "Tri-Technology Device Cryocoolers" conference (TTDC) to be held annually in Baltimore, Maryland starting in 2016, as part of the SPIE DSS meeting. For more information on the venue, please refer to http://spie.org/x6765.xml. The new conference will focus on engineering and device-oriented research on cryogenic optical refrigeration, as well as thermoelectric and mechanical cryocoolers. At the same time, our conference within the Photonics West meeting will now focus more on the fundamental science of solid state cryocoolers, which would also include novel developments in fundamental aspects of thermoelectric coolers (TEC). We already covered TECs within our conference in 2013, resulting in a fruitful scientific exchange between the two fields. We would like to continue on this thread. Therefore, in light of these changes and to reflect the expanding scope of our conference we, together with the Chairs of the TTDC conference, and in agreement with SPIE representatives, have decided to rename our meeting to "Optical and Electronic Cooling of Solids", starting in 2016. We invite you to consider your participation in both conferences and look forward to your exciting submissions next year. As always, please stay tuned for new announcements later in the year.

Finally, we would like to take this opportunity to thank all members of the Program Committee and the SPIE staff for their help in organizing another very successful SPIE Laser Refrigeration of Solids Conference. Thank you to all the speakers, presenters and participants for sharing their novel developments and new insights, as well as active discussions, making 2015 another successful year for our conference.

\section{Richard I. Epstein Denis V. Seletskiy Mansoor Sheik-Bahae}

